\title{
Determination of boron and fluoride sources in groundwater: Batch dissolution of carbonate rocks in water
}

\author{
MARGE UPPIN* and ENN KARRO \\ Department of Geology, Institute of Ecology and Earth Sciences, University of Tartu, Ravila 14A, 50411 Tartu, Estonia
}

(Received January 7, 2013; Accepted July 14, 2013)

\begin{abstract}
High natural fluoride (up to $6.1 \mathrm{mg} / \mathrm{l}$ ) and boron (up to $2.1 \mathrm{mg} / \mathrm{l}$ ) concentrations in groundwater are recorded in western Estonia, where a carbonaceous Silurian-Ordovician aquifer system is the main source of drinking water. The aim of this study is to examine the dissolution of boron and fluoride from different carbonate rocks using batch dissolution tests. The total boron and fluorine concentration within carbonate rocks varies between 100-1000 and 5-150 mg/kg, respectively. Generally, boron and fluoride concentrations increase as the amount of terrigenous material in the rock increases. Laboratory leaching experiments showed that the amount of leached boron and fluoride was proportional to the content of these elements in the rock samples. Further, boron and fluoride concentrations in leachates were positively correlated with the amount of terrigenous material in rocks. Both boron and fluoride concentrations in leachates continually rose over 49 days of leaching. Long-term water-rock interaction is responsible for the high boron and fluoride contents in groundwater of western Estonia.
\end{abstract}

Keywords: boron, fluoride, carbonate rock, water-rock interaction, batch dissolution

\section{INTRODUCTION}

Low concentrations of fluoride $\left(\mathrm{F}^{-}\right)$in drinking water have a beneficial effect on dental health by reducing the incidence of caries, and long-term exposure to excessive fluoride is known to give rise to dental and skeletal fluorosis (Billings et al., 2004; WHO, 2008). Experiments with animals have shown that excessive concentrations of boron (B) in drinking water lead to malfunctioning of the reproductive system e.g., reduced fertility and sterility, low fetal weights. Incidences of metabolistic disorders and acute neurological effects have also been observed (Price et al., 1996; WHO, 2008). The studies regarding effects of boron exposure in humans are few, but the minimal data available report short-term irritant effects of the upper respiratory tract (Garabrant et al., 1985; Wegman et al., 1994). Additionally, a study by Chang et al. (2006) reported a positive relationship between industrial B exposure and reproductive health. Because of their impact upon human health, the occurrence of $\mathrm{F}^{-}$and $\mathrm{B}$ in groundwater is an important aspect of hydrochemistry, and therefore has been studied widely. However, few studies focus on water-rock interaction as a source of $\mathrm{F}^{-}$and $\mathrm{B}$ in groundwater (Özgur, 2001; Saxena and Ahmed, 2001; Chae et al., 2006; Xu et al., 2006; Abdelgawad et al., 2009).

*Corresponding author (e-mail: marge13@ut.ee)

Copyright (C) 2013 by The Geochemical Society of Japan.
F occurs in water primarily as the negatively charged $\mathrm{F}^{-}$ion. It is mainly released into groundwater through weathering and leaching of F-containing minerals in rocks. $\mathrm{F}$ is abundant in various rock forming minerals, e.g., fluorite, apatite, micas, amphiboles, and certain clay minerals. Because of similar ionic radii, $\mathrm{F}^{-}$can replace the hydroxyl ion $\left(\mathrm{OH}^{-}\right)$in many minerals. Fluorite $\left(\mathrm{CaF}_{2}\right)$ has been generally considered as a dominant source of groundwater $\mathrm{F}^{-}$, however, its solubility in fresh water is low (Hem, 1985; Kundu et al., 2001; Saxena and Ahmed, 2003; Sujatha, 2003; Rafique et al., 2008; Naseem et al., 2010; Reddy et al., 2010). It is also suggested that high $\mathrm{F}^{-}$concentrations in groundwater may result from dissolution of biotite and apatite, which can contain significant amounts of $\mathrm{F}$ at the $\mathrm{OH}^{-}$sites of their octahedral sheet (Hem, 1985; Rafique et al., 2008; Desbarats, 2009; Reddy et al., 2010). High F concentrations are also associated with volcanic activity. Thus, elevated concentrations of $\mathrm{F}^{-}$are often found in geothermal waters (Kundu et al., 2001; Desbarats, 2009). Fresh volcanic ash may be rich in $\mathrm{F}^{-}$, and ash interbedded with other sediments can contribute to high $\mathrm{F}^{-}$concentrations in groundwater in such areas (Hem, 1985).

It has been observed that elevated B concentrations in groundwater are often associated with high $\mathrm{F}^{-}$concentrations (Queste et al., 2001; Earle and Krogh, 2006; Desbarats, 2009). Similarly to $\mathrm{F}^{-}$, B is released into the groundwater mainly through the weathering of rocks, seawater intrusion into aquifers, and volcanic activity 


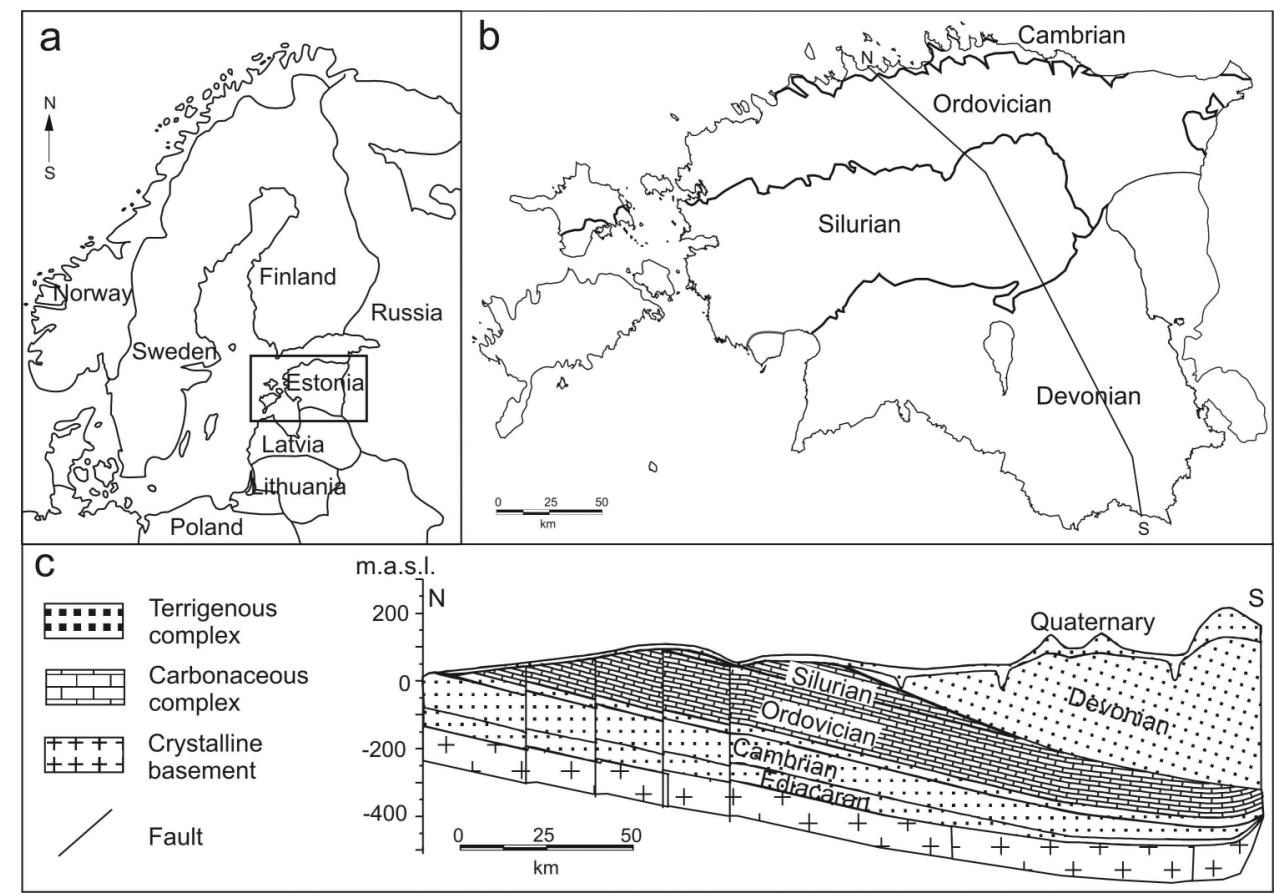

Fig. 1. Location (a) and geological map (b), and a north-south geological cross-section (c) of the area. The line indicates the position of the cross section.

(Hem, 1985; Gemici and Tarcan, 2002; Pennisi et al., 2006). In aqueous solutions, $B$ is mostly present as the borate anion- $\mathrm{B}(\mathrm{OH})_{4}{ }^{-}$- and undissociated boric acid$\mathrm{B}(\mathrm{OH})_{3}$ - (Mather and Porteous, 2001; Gonfiantini and Pennisi, 2006; Pennisi et al., 2006). The distribution of these species depends on the $\mathrm{pH}$ of the aqueous environment. At $\mathrm{pH}$ of $\sim 7$, most $\mathrm{B}$ is present in the form of $\mathrm{B}(\mathrm{OH})_{3}$. The borate ion fraction gradually increases with increasing $\mathrm{pH}$ (Gemici and Tarcan, 2002; Gonfiantini and Pennisi, 2006).

According to the European Union drinking water directive (Council Directive 98/83/EC, 1998), the permissible limits for $\mathrm{F}^{-}$and $\mathrm{B}$ are $1.5 \mathrm{mg} / \mathrm{l}$ and $1 \mathrm{mg} / \mathrm{l}$, respectively. Excessive concentrations of these elements are frequently encountered in western Estonia, where a carbonate Silurian-Ordovician aquifer system is the most prominent drinking water source (Karro et al., 2006, 2009; Karro and Uppin, 2013). The natural concentrations of B and $\mathrm{F}^{-}$in western Estonian groundwater reach up to 2.1 and $6.1 \mathrm{mg} / \mathrm{l}$, respectively. Health problems related to drinking water in Estonia are mainly caused by the high levels of $\mathrm{F}^{-}$and B in groundwater (Indermitte et al., 2009; Indermitte, 2010). Despite the health concerns of elevated $\mathrm{F}^{-}$and $\mathrm{B}$ concentrations in drinking water, the geochemistry of those elements in groundwater has not been studied thoroughly in Estonia. Thus, laboratory experiments on batch dissolution of carbonate rocks were performed in this study.
One factor controlling the groundwater chemistry is the lithological composition of water-bearing rocks. The presence of $\mathrm{F}$ and $\mathrm{B}$ bearing minerals in the host rock and their interaction with water are considered to be the main causes for $\mathrm{F}^{-}$and $\mathrm{B}$ enrichment in groundwater. This study aims to determine the geological sources of $\mathrm{F}^{-}$and $\mathrm{B}$ and to assess their dissolution processes, focusing on the interaction of water and different carbonate rocks. The results of this study could aid in the development of groundwater wells that meet water quality requirements with regard to $\mathrm{F}^{-}$and $\mathrm{B}$.

\section{STUdY AREA}

Estonia, the northernmost of the Baltic countries, is situated in the north-east of Europe. It lies on the east coast of the Baltic Sea and has an area of $45,227 \mathrm{~km}^{2}$. Geologically, Estonia is located in the north-western part of the East-European Platform. The sedimentary beds of the East-European Platform lie on the southern slope of the Baltic Shield, and decline southward at about 3-4 m/ $\mathrm{km}$. The Estonian Paleoproterozoic basement is overlain by Neoproterozoic (Ediacaran) and Paleozoic (Cambrian, Ordovician, Silurian and Devonian) sedimentary rocks, covered by Quaternary deposits (Fig. 1) (Raukas and Teedumäe, 1997).

Both the Ordovician and Silurian sequences in Estonia consist mainly of shallow water carbonates-limestone, 
dolomite, and marlstone with clayey interlayers. An exception is the basal part of the Ordovician sequence, which contains terrigenous sediments-silty and clayey sandstones and graptolite argillites. Several clay-rich altered volcanic ash beds-K-bentonites-are also recorded in the Silurian and Ordovician stratigraphic record (Hints et al., 2008; Kiipli et al., 2008; Somelar et al., 2010).

Hydrogeologically, Estonian sedimentary rocks form a typical artesian basin, wherein five aquifer systems (Middle-Devonian, Middle-Lower-Devonian, SilurianOrdovician, Ordovician-Cambrian, and CambrianVendian) are isolated from each other by impervious beds. Quaternary deposits, consisting predominantly of glacial till and glacio-lacustrine sandy loam, form the uppermost aquifer system, which is used as a domestic drinking water source (Perens and Vallner, 1997).

Ordovician and Silurian carbonate rocks form the Silurian-Ordovician aquifer system (hereafter S-O aquifer system), which is an important, and in places the only, source of drinking water in central and western Estonia and on islands of the West-Estonian archipelago. The upper $30 \mathrm{~m}$ of the $\mathrm{S}-\mathrm{O}$ aquifer system is extremely cavernous, with numerous cracks and fissures. The water in the fissure systems and karst cavities of the carbonate bedrock is fast-flowing. Silurian and Ordovician carbonate rocks have fragmentary 1-2 m thick water-conducting zones with parallel lamination and an abundance of fissures, where groundwater flows in a lateral direction. These zones are separated from each other by $5-10 \mathrm{~m}$ thick layers in which groundwater flows predominantly in vertical fissures. The caverns and fissures decrease in deeper part of the $\mathrm{S}-\mathrm{O}$ aquifer system and the aquifer system transforms into an aquitard (Perens and Vallner, 1997).

The $\mathrm{S}-\mathrm{O}$ aquifer system has an $\mathrm{HCO}_{3}-\mathrm{Ca}-\mathrm{Mg}$ and $\mathrm{HCO}_{3}-\mathrm{Mg}-\mathrm{Ca}$ water type with total dissolved solids (TDS) mainly below $0.6 \mathrm{~g} / \mathrm{l}$ in the upper $30-50 \mathrm{~m}$ portion. In coastal areas and greater depths the concentration of $\mathrm{Cl}^{-}$and $\mathrm{Na}^{+}$in the groundwater increases and an $\mathrm{HCO}_{3}-\mathrm{Cl}-\mathrm{Na}-\mathrm{Mg}-\mathrm{Ca}$ water type with TDS between $0.3-$ $1.5 \mathrm{~g} / \mathrm{l}$ is widespread (Perens et al., 2001).

\section{Materials AND Methods}

Simple batch dissolution experiments were carried out on 20 different carbonate rock (limestone, dolomite, clayey limestone, clayey dolomite, and marlstone) samples selected from 91 rock samples previously analyzed by Uppin and Karro (2012). The chemical composition of carbonate rocks was analyzed at ACME Analytical Laboratories Ltd., Vancouver, Canada in 2008-2010, where $\mathrm{SiO}_{2}, \mathrm{Al}_{2} \mathrm{O}_{3}, \mathrm{Fe}_{2} \mathrm{O}_{3}, \mathrm{MgO}, \mathrm{CaO}, \mathrm{Na}_{2} \mathrm{O}, \mathrm{K}_{2} \mathrm{O}, \mathrm{TiO}_{2}$, $\mathrm{P}_{2} \mathrm{O}_{5}, \mathrm{MnO}, \mathrm{Cr}_{2} \mathrm{O}_{3}, \mathrm{Ba}, \mathrm{Sr}, \mathrm{Cu}, \mathrm{Ni}, \mathrm{Co}, \mathrm{B}$, and $\mathrm{F}$ concentrations were measured. Rock samples were crushed and pulverized to a 200 -mesh-size and dried at $105^{\circ} \mathrm{C}$ prior to analysis. The chemical composition of the rocks was determined using standard Inductively Coupled Plasma Emission Spectroscopy (ICP-ES) and Inductively Coupled Plasma Mass Spectrometry (ICP-MS) techniques. F concentrations were analyzed by specific ion electrode.

The mineral composition (quartz, calcite, dolomite, apatite, K-feldspar, albite, illite/illite-smectite, kaolinite, chlorite, pyrite, and biotite) of the rock samples were determined via using the Rietveld X-ray powder diffractometry (XRD) technique at Department of Geology, University of Tartu. Ground and homogenized unoriented powder samples were measured on a Bruker D8 diffractometer using $\mathrm{Ni}$-filtered $\mathrm{Cu} K$ a radiation over the range $2-70^{\circ} 2 \theta$, with a scan step of $0.02^{\circ} 2 \theta$ and a count time of $2 \mathrm{~s}$ per step. Quantitative mineral composition was determined by full-profile Rietveld analysis using SIROQUANT $^{\mathrm{TM}}$ software system (Taylor, 1991; Ward $e t$ $a l ., 2001)$. The full profile XRD pattern Rietveld method considers the integrated intensities of the particular diffractogram peaks and compares natural and artificial mixtures along the whole length of the diffractogram, thus providing significantly more information for mineral quantification (Ward et al., 2001).

Leaching tests of carbonate rocks were carried out in tightly capped conical polyethylene flasks $(500 \mathrm{ml})$, where 30 g powdered rock samples (mesh size $<1 \mu \mathrm{m}$ ) were treated with $300 \mathrm{ml}$ distilled water. Batch dissolution tests were performed at room temperature $\left(20^{\circ} \mathrm{C}\right)$ using a shaker table (GFL 3005) at a constant shaking rate of 150 $\mathrm{rpm}$. The leachates were filtered using $45 \mu \mathrm{m}$ resin and refrigerated until analysis. After 48 hours, all the 20 leachate samples were analyzed for $\mathrm{F}^{-}$and $\mathrm{B}$; of these, 7 samples were also analyzed for main cations $\left(\mathrm{Ca}^{2+}, \mathrm{Mg}^{2+}\right.$, $\mathrm{K}^{+}$, and $\left.\mathrm{Na}^{+}\right)$and anions $\left(\mathrm{Cl}^{-}, \mathrm{SO}_{4}{ }^{2-}\right.$, and $\left.\mathrm{HCO}_{3}{ }^{-}\right)$. $\mathrm{B}$ concentrations in leachates were determined colorimetrically (Nicolet Evolution 300) using Azomethine-H method (Watson, 1998). $\mathrm{F}^{-}, \mathrm{Ca}^{2+}, \mathrm{Mg}^{2+}, \mathrm{K}^{+}, \mathrm{Na}^{+}, \mathrm{Cl}^{-}$, and $\mathrm{SO}_{4}{ }^{2-}$ concentrations were analyzed using an ion-chromatograph (Dionex ICS-1000) at Department of Geology, University of Tartu. The accuracy and precision of analyses were tested by running duplicate analyses on selected samples. In addition, the $\mathrm{HCO}_{3}{ }^{-}$concentrations of the solutions were determined potentiometrically in the Tartu laboratory of Estonian Environmental Research Centre.

Long-term leaching experiments were continued with the 7 samples from the initial leaching test for 49 days. Leachate samples were taken after 7, 14, and 49 days. The batches were designed to maintain a constant waterrock ratio of 10:1. Sufficient amounts of rock powder and distilled water were used to enable repeated samplings of small solution aliquots $(6 \mathrm{ml})$ without significantly changing the water-rock ratio. $\mathrm{pH}$ values were obtained using a pH meter (Mettler Toledo SG8-ASK) in all experiments 
at specific time intervals.

The saturation indices (SI) of fluorite $\left(\mathrm{CaF}_{2}\right)$ and calcite $\left(\mathrm{CaCO}_{3}\right)$ in groundwater samples were calculated using the computer program PHREEQC (Parkhurst and Appelo, 1999).

\section{RESUlTS AND DISCUSSION}

The $\mathrm{S}-\mathrm{O}$ aquifer system in Estonia consists of different carbonate rocks, mainly limestones, dolomites, and marlstones with more clayey interlayers, including clayrich altered volcanic ash beds-K-bentonites (Nestor and Einasto, 1997; Hints et al., 2008; Kiipli et al., 2008; Somelar et al., 2010). Leaching of the host rocks is considered to be the major natural source of $\mathrm{F}^{-}$and $\mathrm{B}$ in groundwater; therefore, chemical composition of aquifer forming rocks has been examined. B and $\mathrm{F}$ concentrations in Estonian limestones and dolomites vary between $5-20 \mathrm{mg} / \mathrm{kg}$ and $100-500 \mathrm{mg} / \mathrm{kg}$, and can reach up to 150 $\mathrm{mg} / \mathrm{kg}$ and $1000 \mathrm{mg} / \mathrm{kg}$ in marlstones, respectively. Furthermore, K-bentonites are rich in B (50-1000 $\mathrm{mg} / \mathrm{kg}$ ) and $\mathrm{F}$ (400-4500 mg/kg). Generally, an increase in clay content is followed by an increase in the B and F concentrations in carbonate rocks (Uppin and Karro, 2012). This can be seen in Fig. 2. In addition, Fig. 2 presents the strong positive correlation between $\mathrm{B}$ and $\mathrm{F}$ concentrations in carbonate rocks. $\mathrm{B}$ and $\mathrm{F}$ concentrations of the rock samples used in the batch dissolution tests are shown in Table 1 .

Several studies have suggested that F-containing minerals like fluorite, micas (biotite), apatite, amphiboles, and clay minerals could be possible sources of $\mathrm{F}^{-}$in groundwater (Hem, 1985; Kundu et al., 2001; Saxena and Ahmed, 2003; Sujatha, 2003; Rafique et al., 2008; Desbarats, 2009; Naseem et al., 2010; Reddy et al., 2010). $\mathrm{B}$ is associated with clay minerals, but may also occur as an accessory constituent of tourmaline, biotite, and amphiboles (Hem, 1985; Gemici and Tarcan, 2002; Gonfiantini and Pennisi, 2006; Pennisi et al., 2006). Based on the XRD analyses (Table 2), the main constituents of the carbonate rock samples used in the leaching tests are determined to be calcite and dolomite (up to $99 \%$, depending on the rock type) with the addition of quartz (0.7$31.1 \%)$, K-feldspar (0.5-6.9\%), and illitic clay minerals $(0.8-32.5 \%)$. Additionally, small amounts of apatite (up to $1.2 \%$ ), albite (up to $1.9 \%$ ), chlorite (up to $8.3 \%$ ), and pyrite (up to $1.2 \%$ ) can be found in some rock samples. Biotite was not detected in the studied carbonate rocks; concentrations of up to $4.2 \%$ of the whole rock occur only in K-bentonite samples (Hints et al., 2008). Among the studied carbonate rocks, the proportion of illitic clay minerals (11.7-32.5\%) is highest in the marlstones (Table 2). Estonian carbonate rocks containing apatite tend to be rich in F (Uppin and Karro, 2012). However, apatite is

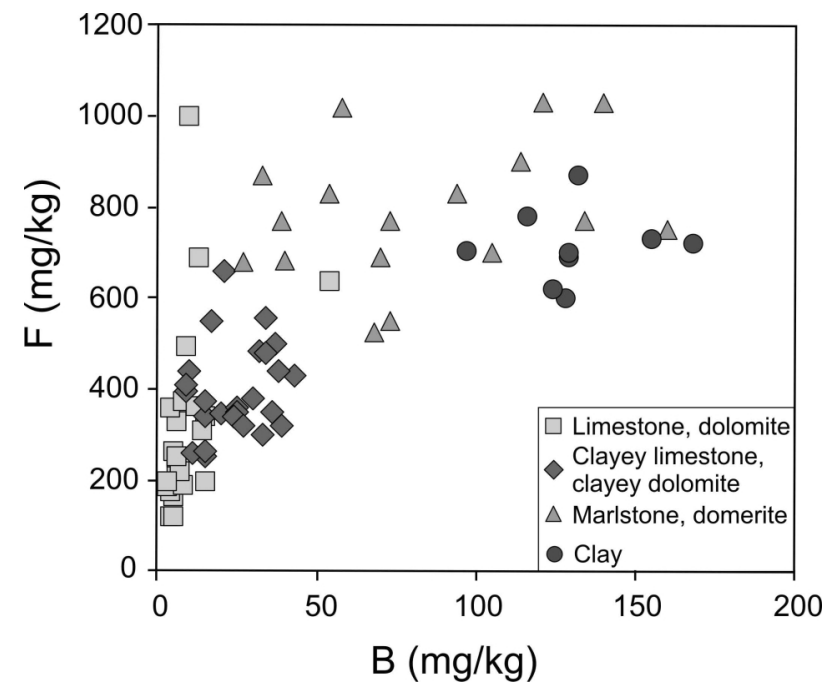

Fig. 2. Bivariate plot of $F$ and $B$ contents in the different carbonate rocks that form Silurian-Ordovician aquifer system (data from Uppin and Karro, 2012).

probably not a significant source of $\mathrm{F}^{-}$in the groundwater because of its low solubility (Desbarats, 2009). In this study, the apatite content of rock samples was low (below $1.2 \%$ ) and no correlation between apatite and $\mathrm{F}^{-}$concentration in the leachates was detected.

A previous study focusing on the chemical composition of aquifer forming carbonate rocks (Uppin and Karro, 2012) showed that lower $\mathrm{CaO} / \mathrm{Al}_{2} \mathrm{O}_{3}$ ratios, representative of terrigenous material, were accompanied by elevated $\mathrm{B}$ and $\mathrm{F}$ concentrations in carbonate rocks. Furthermore, higher $\mathrm{B}$ and $\mathrm{F}$ concentrations in rocks were related to lower $\mathrm{K}_{2} \mathrm{O} / \mathrm{Al}_{2} \mathrm{O}_{3}$ ratios, common to clayey material (mainly illitic clay minerals) in carbonate rocks in Estonia. Overall, elevated B and F concentrations in carbonate rocks were clearly concentrated in the terrigenous fraction of the rock and were bound to clay mineral phases. The terrigenous material in the Silurian and Ordovician carbonate rocks consists mainly of clay and silt fractions with sand occurring only occasionally.

The dissolution rate of chemical elements, including $\mathrm{B}$ and $\mathrm{F}$, into groundwater depends on numerous factors such as the chemical and mineralogical composition of aquifer forming rocks, the groundwater chemistry, $\mathrm{pH}$, and the temperature of the environment, and the time available for water-rock interaction, etc. All these factors should be considered when interpreting the formation of groundwater chemistry. In order to estimate and compare the contribution of the different rock types to the natural sources of B and F, the influence of other environmental factors (e.g., differences in groundwater chemistry) should be minimized. Simple laboratory batch dissolution tests enable the creation of uniform conditions 
Table 1. The concentrations of $B$ and $F$ in aquifer forming carbonate rocks and in leachates after 2, 7, 14, and 49 days of batch dissolution tests

\begin{tabular}{|c|c|c|c|c|c|c|c|c|c|c|c|}
\hline & & \multicolumn{2}{|c|}{ Rock samples (mg/kg) } & \multicolumn{8}{|c|}{ Leachates $(\mathrm{mg} / \mathrm{l})$} \\
\hline & & \multirow[b]{2}{*}{ B } & \multirow[b]{2}{*}{$\mathrm{F}$} & \multicolumn{2}{|c|}{2 days } & \multicolumn{2}{|c|}{7 days } & \multicolumn{2}{|c|}{14 days } & \multicolumn{2}{|c|}{49 days } \\
\hline & & & & B & $\mathrm{F}^{-}$ & B & $\mathrm{F}^{-}$ & B & $\mathrm{F}^{-}$ & B & $\mathrm{F}^{-}$ \\
\hline 1 & Limestone & 11 & 260 & 0.10 & 0.43 & & & & & & \\
\hline 2 & Limestone & 4 & 176 & 0.05 & 0.10 & & & & & & \\
\hline 3 & Dolomite & 8 & 374 & 0.08 & 0.16 & 0.12 & 0.20 & 0.13 & 0.17 & 0.19 & 0.21 \\
\hline 4 & Dolomite & 7 & 220 & 0.05 & 0.08 & 0.10 & 0.10 & 0.08 & 0.09 & 0.15 & 0.09 \\
\hline 5 & Dolomite & 9 & 495 & 0.14 & 0.16 & & & & & & \\
\hline 6 & Dolomite & 12 & 363 & 0.05 & 0.38 & & & & & & \\
\hline 7 & Dolomite & 36 & 350 & 0.15 & 0.17 & & & & & & \\
\hline 8 & Clayey limestone & 40 & 683 & 0.19 & 0.52 & 0.27 & 0.57 & 0.27 & 0.57 & 0.28 & 0.60 \\
\hline 9 & Clayey limestone & 37 & 500 & 0.21 & 0.38 & 0.26 & 0.43 & 0.23 & 0.42 & 0.29 & 0.45 \\
\hline 10 & Clayey limestone & 9 & 396 & 0.07 & 0.34 & 0.07 & 0.44 & 0.09 & 0.48 & 0.13 & 0.51 \\
\hline 11 & Clayey limestone & 15 & 341 & 0.16 & 0.18 & 0.13 & 0.20 & 0.17 & 0.21 & 0.42 & 0.24 \\
\hline 12 & Clayey limestone & 10 & 440 & 0.05 & 0.35 & & & & & & \\
\hline 13 & Clayey limestone & 15 & 341 & 0.05 & 0.22 & & & & & & \\
\hline 14 & Clayey limestone & 9 & 410 & 0.04 & 0.11 & 0.03 & 0.15 & 0.06 & 0.19 & 0.09 & 0.26 \\
\hline 15 & Clayey dolomite & 21 & 660 & 0.16 & 0.27 & & & & & & \\
\hline 16 & Clayey dolomite & 17 & 550 & 0.06 & 0.38 & & & & & & \\
\hline 17 & Clayey dolomite & 3 & 187 & 0.05 & 0.26 & & & & & & \\
\hline 18 & Marlstone & 43 & 430 & 0.50 & 0.60 & & & & & & \\
\hline 19 & Marlstone & 68 & 525 & 0.71 & 0.45 & & & & & & \\
\hline 20 & Marlstone & 140 & 1029 & 1.40 & 0.85 & & & & & & \\
\hline
\end{tabular}

Table 2. Whole-rock semi-quantative mineral composition of the Silurian and Ordovician carbonate rocks (wt.\%). I-S, illite-smectite

\begin{tabular}{|c|c|c|c|c|c|c|c|c|c|c|}
\hline & & Calcite & Dolomite & Quartz & K-feldspar & Albite & Illite/I-S & Chlorite & Apatite & Pyrite \\
\hline 1 & Limestone & 85.1 & 5.4 & 2.7 & 1.3 & 1.3 & 3.5 & & & 0.8 \\
\hline 2 & Limestone & 99.3 & 0.1 & 0.7 & & & & & & \\
\hline 3 & Dolomite & 37.9 & 54.2 & 2.6 & 2.4 & & 1.3 & 1.2 & & 0.4 \\
\hline 4 & Dolomite & & 90.8 & 3.5 & 3.4 & 0.8 & 0.8 & & & 0.7 \\
\hline 5 & Dolomite & & 96.8 & 1.1 & 0.5 & & 0.9 & & & \\
\hline 6 & Dolomite & & 91.6 & 3.6 & 3.0 & 0.5 & 0.9 & & & \\
\hline 7 & Dolomite & & 90.0 & 3.0 & 1.4 & & 3.7 & 1.3 & & \\
\hline 8 & Clayey limestone & 59.2 & 19.4 & 9.2 & 4.3 & & 5.3 & 2.3 & & \\
\hline 9 & Clayey limestone & 86.5 & 2.3 & 4.3 & 1.7 & & 3.3 & & 0.8 & 1.2 \\
\hline 10 & Clayey limestone & 81 & 3.9 & 4.5 & 3.7 & & 4.0 & 1.5 & & 1.4 \\
\hline 11 & Clayey limestone & 80.4 & 6.5 & 6.0 & 2.7 & & 1.9 & & 1.2 & 0.8 \\
\hline 12 & Clayey limestone & 53.7 & 26.5 & 11.4 & 4.0 & 0.9 & 1.5 & & & \\
\hline 13 & Clayey limestone & 84.9 & 4.0 & 2.1 & 2.3 & 1.0 & 2.6 & & 1.2 & 0.8 \\
\hline 14 & Clayey limestone & 48.3 & 41.1 & 5.9 & 3.1 & & 1.3 & & & 0.2 \\
\hline 15 & Clayey dolomite & 1.2 & 83.8 & 5.6 & 2.4 & 1.1 & 3.3 & 2.1 & & \\
\hline 16 & Clayey dolomite & 29.3 & 51.6 & 3.8 & 2.2 & 1.9 & 7.5 & 2.2 & & 1.2 \\
\hline 17 & Clayey dolomite & & 85.9 & 6.6 & 1.9 & 1.2 & 2.7 & & & \\
\hline 18 & Marlstone & 68.9 & 5.8 & 8.1 & 2.1 & & 11.7 & 1.9 & 1.1 & \\
\hline 19 & Marlstone & 38.7 & 8.6 & 31.1 & 4.0 & & 15.0 & 1.8 & & 0.9 \\
\hline 20 & Marlstone & 17 & 14.4 & 18.6 & 6.9 & 1.2 & 32.5 & 8.3 & & 1.0 \\
\hline
\end{tabular}

for leaching experiments. In this study, 20 crushed carbonate rock samples were leached in distilled water for two days. The long-term test continued with seven rock samples. The results of the test, focusing on $\mathrm{B}$ and $\mathrm{F}^{-}$ concentrations in leachates, are summarized in Table 1.
After two days of leaching, B concentrations varied between $0.04-1.40 \mathrm{mg} / \mathrm{l}$, and the $\mathrm{F}^{-}$concentration ranged between $0.10-0.85 \mathrm{mg} / \mathrm{l}$ in the leachates. The highest amounts of $\mathrm{B}$ and $\mathrm{F}^{-}$were leached out from the marlstone samples. A basic assumption is that the concentrations of 

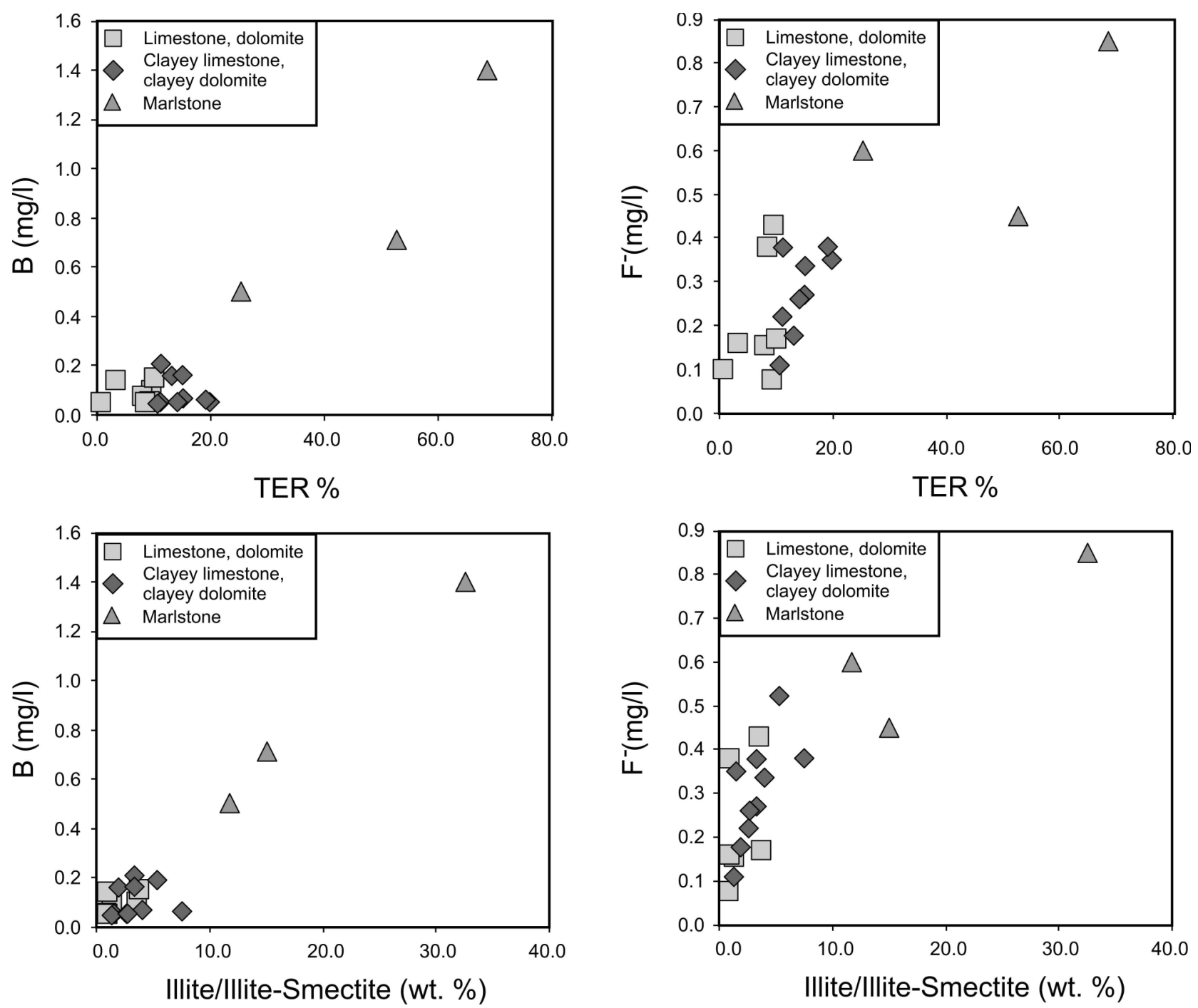

Fig. 3. $F^{-}$and B concentrations in leachates plotted against the amount of terrigenous compounds and illite/illite-smectite contents in carbonate rocks.

$\mathrm{B}$ and $\mathrm{F}^{-}$in the leachates depend on the abundance of these elements in rocks. However, this is only a first approximation. The results after two days of the experiment showed that the leachate $\mathrm{B}$ and $\mathrm{F}^{-}$concentrations were positively correlated with the amount of the terrigenous material as well as illitic clay minerals in the rock samples (Fig. 3). According to several studies (Saxena and Ahmed, 2003; Sujatha, 2003; Gonfiantini and Pennisi, 2006; Pennisi et al., 2006; Rafique et al., 2008; Naseem et al., 2010), significant amounts of B and F in rocks are considered to be related to clay minerals. Ion-exchange and adsorption are the most typical processes through which $\mathrm{B}$ and $\mathrm{F}$ are bound to clay minerals. A thorough study by Du et al. (2011) describes the adsorption mechanisms of $\mathrm{F}^{-}$on kaolinite, montmorillonite, chlorite, and illite. In this study, leachate concentrations of $\mathrm{B}(r=0.91)$ and $\mathrm{F}^{-}(r=0.81)$ show a good correlation with $\mathrm{K}_{2} \mathrm{O}$ concentration in the carbonate rocks. Considering the mineralogical composition of the carbonate rocks (Table 2), it can be assumed that $\mathrm{B}$ and $\mathrm{F}$ originate from the same minerals, most likely illitic clay minerals. Thus, B and F in groundwater are mainly leached out from clayey material, such as clayey limestones, clayey dolomites, marlstones, and domerites. Consequently, it can be presumed that the long-term leaching of clayey carbonate rocks provides the elevated $\mathrm{F}^{-}$and $\mathrm{B}$ concentrations in the groundwater of western Estonia.

During the 49 days of the leaching test, $\mathrm{B}$ and $\mathrm{F}^{-}$concentrations in the solutions continually exhibited an increasing trend (Fig. 4); however, remarkable amounts of $\mathrm{B}$ and $\mathrm{F}$ were leached out during the first week of the test. The same trend was observed during batch dissolu- 

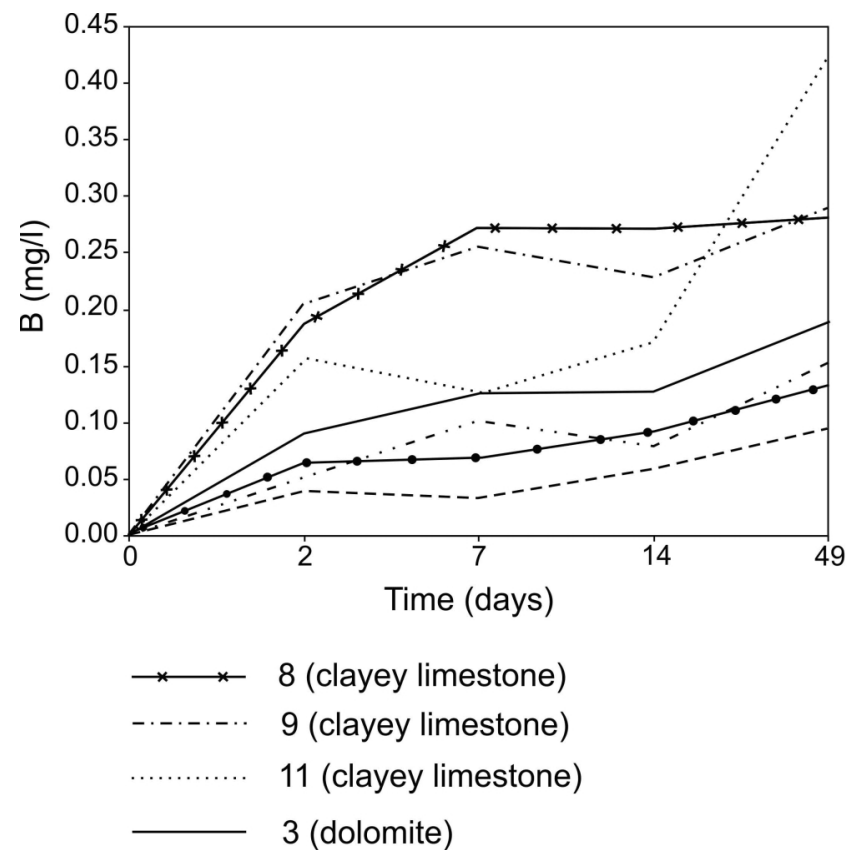
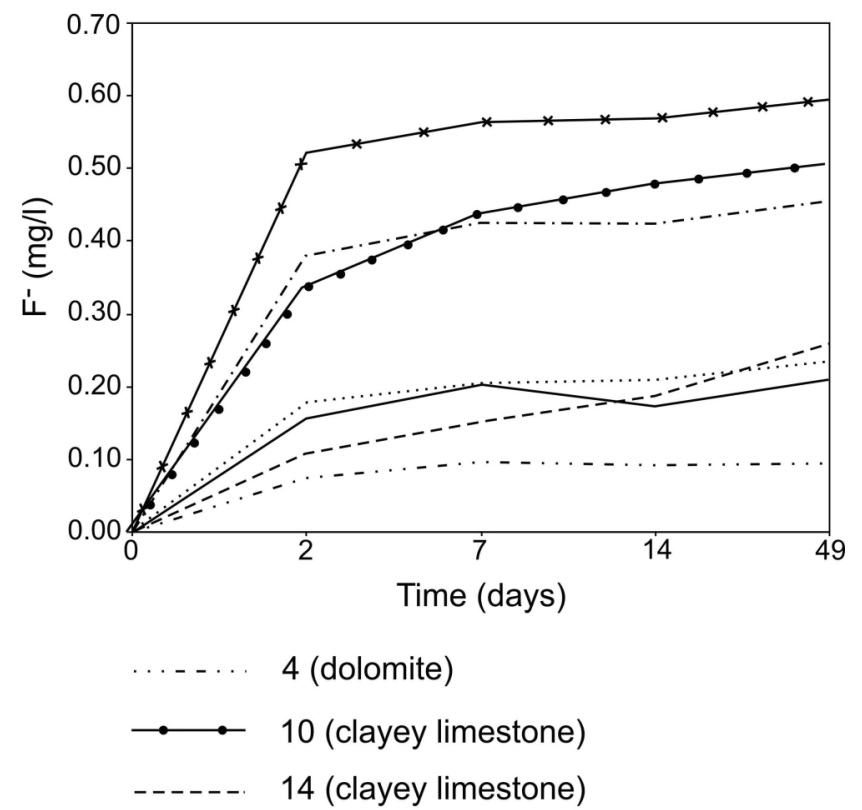

Fig. 4. Variations of $B$ and $F^{-}$concentrations in leachates during the water-rock interaction test. Sample numbers are as shown in Tables 1 and 2 .

tion experiments of granite samples in water (Chae et al., 2006; Abdelgawad et al., 2009), where the leached $\mathrm{F}^{-}$ contents increased rapidly at the beginning of the test with only a only slight increase in its concentration thereafter. Batch dissolution experiments by Chae et al. (2006) showed that $\mathrm{F}^{-}$concentrations approached a maximum value of about $10 \mathrm{mg} / \mathrm{l}$ during the first week of leaching and then decreased to the level of $8 \mathrm{mg} / \mathrm{l}$. Calculated saturation indices showed that the solution approached a saturated or supersaturated state with respect to fluorite after less than $200 \mathrm{~h}$, while calcite saturation was not reached within this time. Therefore, Chae et al. (2006) suggested that fluorite precipitation occurred in the latter part of the experiments, which controlled the $\mathrm{F}^{-}$concentration in the solution. However, the results of the batch dissolution tests of the current study (Fig. 4) as well as the study by Abdelgawad et al. (2009) demonstrate a continuous increasing trend in dissolved $\mathrm{F}^{-}$and $\mathrm{B}$ concentrations. This may indicate that the saturation state of the solution with respect to fluorite was not achieved during the 49-day dissolution tests.

The increase in $\mathrm{B}$ and $\mathrm{F}^{-}$concentrations with reaction time indicates the importance of the residence time of the groundwater in aquifer forming rocks. Generally, the amount of dissolved chemical substances in groundwater increases with depth because of slower water exchange and longer residence times in the aquifer. Deviations from this general tendency in abstracted groundwater can be explained by differences in the constructions of wells, their open intervals, and in the type and structure of the opened rocks. It has been shown that the elevated $\mathrm{F}^{-}$and $\mathrm{B}$ contents in Estonian groundwater are related to deeper wells with short screens opening clayey carbonate rocks (Karro and Uppin, 2013). The long open interval of the drilled well enables the mixing of waters with different chemical compositions, which results in groundwater dilution and lower $\mathrm{F}^{-}$and $\mathrm{B}$ concentrations. Further, high $\mathrm{F}^{-}$and $\mathrm{B}$ concentrations are often associated with alkaline waters rich in $\mathrm{Na}^{+}$and $\mathrm{Cl}^{-}$ions, as shown in several regional studies (Queste et al., 2001; Gemici and Tarcan, 2002; Saxena and Ahmed, 2003; Sujatha, 2003; Chae et al., 2007; Rafique et al., 2008; Desbarats, 2009) as well as in the case of the Estonian Silurian-Ordovician aquifer system (Karro and Uppin, 2013). Groundwater in Silurian and Ordovician carbonate rocks is predominantly of an $\mathrm{HCO}_{3}-\mathrm{Ca}-\mathrm{Mg}$ chemical type with a high $\mathrm{Ca}^{2+}$ concentration and low amounts of $\mathrm{F}^{-}$and $\mathrm{B}$. High $\mathrm{F}^{-}$and $\mathrm{B}$ concentrations are associated mainly with alkaline groundwaters rich in $\mathrm{Na}^{+}$and $\mathrm{Cl}^{-}$ions, represented by $\mathrm{Cl}-\mathrm{HCO}_{3}-\mathrm{Na}$ and $\mathrm{HCO}_{3}-\mathrm{Cl}-\mathrm{Na}$ types of waters. The $\mathrm{pH}$ values of groundwater in $\mathrm{S}-\mathrm{O}$ aquifer system range between 6.76-8.48, and higher values are common to groundwater in West-Estonia (Karro and Rosentau, 2005; Karro and Uppin, 2013). Besides, the average clay content of the Silurian and Ordovician sequences tends to increase from north to south and south-west in Estonia (Nestor and Einasto, 1997). Thus, in the western part of the country, the carbonate rocks are generally represented 
Table 3. The concentrations of main anions, cations $(\mathrm{mg} / \mathrm{l})$, and $\mathrm{pH}$ in leachates used as input data for the calculations of saturation indices

\begin{tabular}{|c|c|c|c|c|c|c|c|c|c|c|c|c|c|c|c|c|c|}
\hline & \multicolumn{8}{|c|}{2 days } & \multicolumn{8}{|c|}{49 days } \\
\hline & & $\mathrm{Cl}^{-}$ & $\mathrm{SO}_{4}{ }^{2-}$ & $\mathrm{HCO}_{3}^{-}$ & $\mathrm{Na}^{+}$ & $\mathrm{K}^{+}$ & $\mathrm{Mg}^{2+}$ & $\mathrm{Ca}^{2+}$ & $\mathrm{pH}$ & $\mathrm{Cl}^{-}$ & $\mathrm{SO}_{4}{ }^{2-}$ & $\mathrm{HCO}_{3}^{-}$ & $\mathrm{Na}^{+}$ & $\mathrm{K}^{+}$ & $\mathrm{Mg}^{2+}$ & $\mathrm{Ca}^{2+}$ & $\mathrm{pH}$ \\
\hline 3 & Dolomite & 13.2 & 3.1 & 59.8 & 10.6 & 6.6 & 7.5 & 8.9 & 8.92 & 18.0 & 8.6 & 168.0 & 12.1 & 6.2 & 18.6 & 28.6 & 7.91 \\
\hline 4 & Dolomite & 17.9 & 48.2 & 96.4 & 9.8 & 5.8 & 24.5 & 23.9 & 8.77 & 19.8 & 136.2 & 192.0 & 11.2 & 6.2 & 47.0 & 43.7 & 8.04 \\
\hline 8 & Clayey limestone & 4.8 & 4.9 & 137.0 & 7.8 & 15.2 & 16.2 & 79.2 & 8.31 & 8.5 & 15.2 & 279.0 & 7.2 & 14.8 & 20.6 & 65.3 & 7.34 \\
\hline 9 & Clayey limestone & 5.0 & 46.9 & 70.8 & 4.3 & 8.8 & 4.6 & 25.1 & 8.53 & 4.5 & 64.4 & 83.0 & 3.0 & 7.1 & 9.2 & 40.6 & 7.95 \\
\hline 10 & Clayey limestone & 5.7 & 21.3 & 80.8 & 1.9 & 4.2 & 5.5 & 25.0 & 7.96 & 9.4 & 70.3 & 102.0 & 3.8 & 6.5 & 7.9 & 58.5 & 7.62 \\
\hline 11 & Clayey limestone & 3.6 & 7.6 & 86.6 & 2.0 & 5.4 & 3.7 & 16.1 & 8.45 & 4.4 & 20.4 & 160.0 & 1.2 & 4.8 & 9.7 & 50.1 & 7.56 \\
\hline 14 & Clayey limestone & 3.7 & 4.8 & 63.4 & 1.8 & 3.0 & 3.2 & 11.8 & 8.87 & 3.7 & 4.0 & 107.0 & 1.8 & 1.6 & 6.4 & 29.6 & 8.06 \\
\hline
\end{tabular}

by clayey limestones and marlstones. Due to the increase in the clay content of the aquifer forming rocks, prolonged groundwater residence time and water-rock interactions, $\mathrm{Ca}^{2+}$ is replaced by $\mathrm{Na}^{+}$through ion-exchange processes, and the $\mathrm{pH}$ value of groundwater slightly increases. This leads to the formation of alkaline groundwater of an $\mathrm{HCO}_{3}-\mathrm{Cl}-\mathrm{Na}$ or $\mathrm{Cl}-\mathrm{HCO}_{3}-\mathrm{Na}$ chemical type, which favors the leaching of $\mathrm{F}^{-}$and $\mathrm{B}$ into the groundwater.

The batch dissolution tests of the current study showed that $\mathrm{pH}$ values of the leachates increased rapidly up to 8.9 during the first days of the experiments due to the consumption of hydrogen ions during the dissolution of carbonate minerals and then decreased gradually to $<8.0$ by the end of the test. Analogous behavior of $\mathrm{pH}$ values was observed in case of a granite dissolution study by Chae et al. (2006), where the solution $\mathrm{pH}$ reached 9.5 at the beginning of the experiment and decreased slightly over the next $500 \mathrm{~h}$, and then stabilized at $\sim 8.0$. Several hydrochemical studies suggest that the $\mathrm{pH}$ value of groundwater is positively correlated with $\mathrm{B}$ and $\mathrm{F}^{-}$(Queste et al., 2001; Gemici and Tarcan, 2002; Chae et al., 2007; Rafique et al., 2008; Desbarats, 2009; Karro and Uppin, 2013). This implies that an alkaline environment preferably favors the release of $\mathrm{F}^{-}$and $\mathrm{B}$ into the water. Thus, the high $\mathrm{pH}$ value at the beginning of the batch dissolution test could be one of the factors that contribute the leaching most of the $\mathrm{F}^{-}$and $\mathrm{B}$ during the first two days.

$\mathrm{F}^{-}$ions released into the groundwater are considered to be controlled by the degree of saturation of fluorite and calcite, and the concentration of $\mathrm{Ca}^{2+}, \mathrm{HCO}_{3}{ }^{-}$, and $\mathrm{Na}^{+}$ions in groundwater, among other natural geochemical processes (Saxena and Ahmed, 2003; Rafique et al., 2008; Mamatha and Rao, 2010). Therefore, the saturation indices (SI) of fluorite and calcite have been calculated using PHREEQC (Parkhurst and Appelo, 1999). Equation (1) is used to calculate the saturation state of water with respect to solid mineral phases:

$$
\mathrm{SI}_{\mathrm{x}}=\log \left[\frac{\mathrm{IAP}}{\mathrm{K}_{\mathrm{x}}}\right]
$$

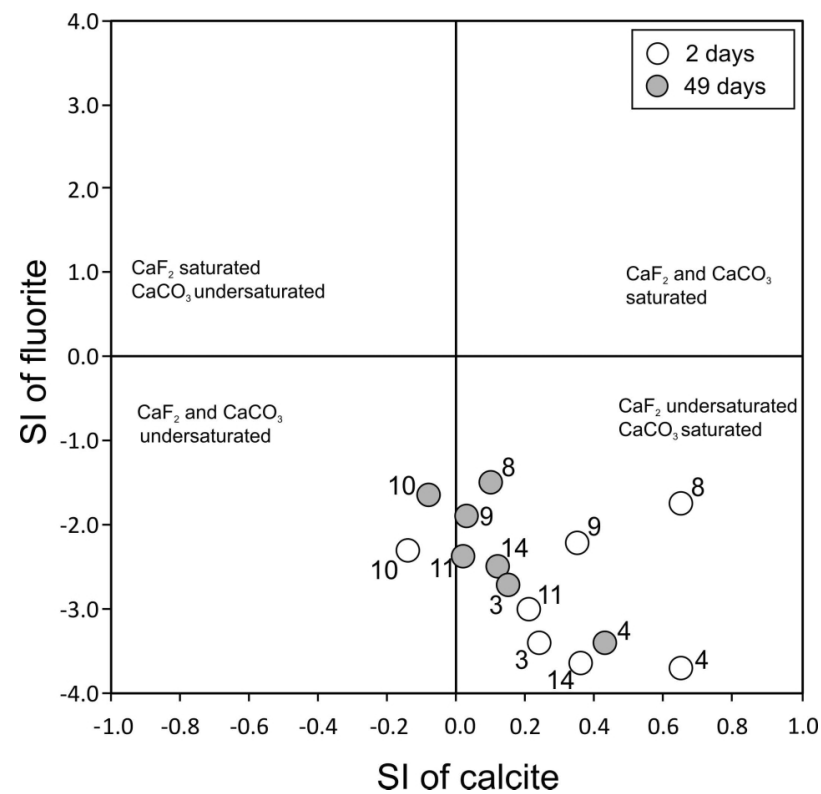

Fig. 5. Calcite saturation index versus fluorite saturation index for leachate samples after 2 and 49 days of the leaching experiments. Sample numbers are as shown in Tables 1 and 2.

where SI is the saturation index of mineral $\mathrm{x}$, IAP is the ion activity product, and $\mathrm{K}_{\mathrm{x}}$ is the equilibrium solubility product of mineral $\mathrm{x}$. A positive saturation index indicates that the solution is supersaturated with mineral $\mathrm{x}$ and the mineral should precipitate out from the solution. A negative value indicates that the solution is undersaturated with respect to mineral $x$. Thus, the observed mineral, if present, should be dissolved. The following equations explain the saturation of groundwater with respect to calcite and fluorite (Sreedevi et al., 2006):

$$
\mathrm{CaCO}_{3}+\mathrm{H}^{+} \rightarrow \mathrm{Ca}^{2+}+\mathrm{HCO}_{3}^{-}
$$

$$
\mathrm{K} 1=\frac{\left[\mathrm{Ca}^{2+}\right]\left[\mathrm{HCO}_{3}^{-}\right]}{\left[\mathrm{H}^{+}\right]}
$$




$$
\begin{aligned}
& \mathrm{CaF}_{2} \rightarrow \mathrm{Ca}^{2+}+2 \mathrm{~F}^{-} \\
& \mathrm{K} 2=\left[\mathrm{Ca}^{2+}\right]\left[\mathrm{F}^{-}\right]^{2}
\end{aligned}
$$

where $\mathrm{K} 1$ and $\mathrm{K} 2$ are the equilibrium solubility products of calcite and fluorite dissolved in water, respectively. Due to the relatively low solubility of fluorite, the occurrence of aqueous $\mathrm{F}^{-}$is predominantly controlled by the availability of free $\mathrm{Ca}^{2+}$ ions in the water. From Eq. (5), it is apparent that a decrease in $\mathrm{Ca}^{2+}$ may be followed by an increase in $\mathrm{F}^{-}$. From Eqs. (3) and (5), the following relation is derived:

$$
\frac{\left[\mathrm{HCO}_{3}^{-}\right]}{\left[\mathrm{H}^{+}\right]\left[\mathrm{F}^{-}\right]^{2}}=\frac{\mathrm{K} 1}{\mathrm{~K} 2}
$$

From Eq. (3), if $\mathrm{pH}$ is constant, an increase in $\mathrm{Ca}^{2+}$ is accompanied by a decrease in $\mathrm{HCO}_{3}{ }^{-}$. Therefore, an increase in $\mathrm{HCO}_{3}{ }^{-}$should be followed by enrichment of $\mathrm{F}^{-}$ in solution.

Saturation indices of calcite and fluorite from selected samples were calculated after 2 days and 49 days of shaking. The input data of the geochemical model included the concentrations of main anions and cations in the leachates, $\mathrm{pH}$ values (Table 3$)$, and temperature $\left(20^{\circ} \mathrm{C}\right)$. Considering the errors in field measurements and SI computation, approximate boundaries for equilibrium zones $(-0.5<\mathrm{SI}<0.5)$ were defined by Carillo-Rivera et al. (2002) and Mamatha and Rao (2010). All samples were near equilibrium with respect to calcite and undersaturated with respect to fluorite (Fig. 5). The fluorite SI slightly increases with reaction time and did not reach equilibrium even after 49 days. Further, the results by Karro and Uppin (2013) showed that the groundwater in S-O aquifer system is undersaturated or in equilibrium with respect to fluorite. Samples approaching equilibrium with respect to fluorite typically have $\mathrm{F}^{-}$concentrations higher than $2 \mathrm{mg} / \mathrm{l}$. This is markedly higher than those analyzed from the leachates (up to $0.6 \mathrm{mg} / \mathrm{l}$ ) during the laboratory tests (Table 1). However, in both cases-laboratory leachates and natural groundwater-samples with higher $\mathrm{F}^{-}$values are saturated with respect to calcite. Thus, $\mathrm{F}^{-}$ concentrations in groundwater can increase as a result of the precipitation of calcite, which removes $\mathrm{Ca}^{2+}$ from solution, allowing more fluorite to be dissolved.

\section{Conchusions}

$\mathrm{B}$ and $\mathrm{F}^{-}$concentrations (up to $2.1 \mathrm{mg} / \mathrm{l}$ and $6.1 \mathrm{mg} / \mathrm{l}$, respectively) are common in groundwater in western Estonia, where the main drinking water resource is a carbonaceous Silurian-Ordovician aquifer system. Leaching of the clayey carbonate rocks that form the aquifer is the probable natural source of $\mathrm{B}$ and $\mathrm{F}^{-}$in alkaline $\mathrm{HCO}_{3}-$ $\mathrm{Cl}-\mathrm{Na}$ or $\mathrm{Cl}-\mathrm{HCO}_{3}-\mathrm{Na}$ types of groundwater in this area. Batch dissolution tests were performed in order to understand the origin of $\mathrm{B}$ and $\mathrm{F}^{-}$rich groundwater in western Estonia and to determine if high $\mathrm{F}^{-}$and $\mathrm{B}$ levels in water could be attributed to certain rock types. B and F contents in Estonian limestones and dolomites vary between $5-20 \mathrm{mg} / \mathrm{kg}$ and $100-500 \mathrm{mg} / \mathrm{kg}$, and reach up to $150 \mathrm{mg} /$ $\mathrm{kg}$ and $1000 \mathrm{mg} / \mathrm{kg}$ in marlstones, respectively. Twenty rock samples were crushed to powder and leached in distilled water for 2 days. The test continued with seven rock samples, and leachate samples were taken on the 7, 14, and 49 day of the test. After 49 days of leaching, B and $\mathrm{F}^{-}$concentrations in solutions showed increasing trend; however, a significant amount of $B$ and $F$ were leached out during the first week of the test. The saturation state of the solution with respect to fluorite was not achieved during the long-term dissolution tests. $\mathrm{B}$ and $\mathrm{F}^{-}$concentrations in the leachates are clearly correlated with terrigenous material and further with the illite/illitesmectite fraction in rock samples, which indicates that the most likely sources of $\mathrm{B}$ and $\mathrm{F}^{-}$in water are ionexchange and adsorption processes associated with clay minerals. Furthermore, $\mathrm{F}^{-}$ions released into the groundwater are controlled by the degree of saturation of fluorite and calcite. F-rich water is saturated with respect to calcite-precipitation of $\mathrm{CaCO}_{3}$ removes $\mathrm{Ca}^{2+}$ from solution allowing more fluorite to be dissolved. The results of this study show that the local geology (rock types) must be considered when developing new water supply wells. The opening of clayey rocks by well screens should be avoided to ensure a safe drinking water supply with appropriate $\mathrm{B}$ and $\mathrm{F}^{-}$concentrations.

Acknowledgments-This study has been carried out with the financial support of Estonian Science Foundation Grants No. 7403 and 9172. The XRD analyses were carried out with the assistance of Dr. Peeter Somelar at Department of Geology, University of Tartu. The chemical analyses of rock samples were performed at ACME Analytical Laboratories Ltd., Canada. The leachates were analyzed at Department of Geology, University of Tartu with the assistance of Dr. Martin Liira and in Tartu Laboratory of Estonian Environmental Research Centre. The authors are grateful to Dr. Koshi Yamamoto and an anonymous reviewer for their constructive comments and suggestions, which helped to improve the quality of the paper.

\section{REFERENCES}

Abdelgawad, A. M., Watanabe, K., Takeuchi, S. and Mizuno, T. (2009) The origin of fluoride-rich groundwater in Mizunami area, Japan-Mineralogy and geochemistry implications. Eng. Geol. 108, 76-85. 
Billings, R. J., Berkowitz, R. J. and Watson, G. (2004) Teeth. Pediatrics 113, 1120-1127.

Carillo-Rivera, J. J., Cardona, A. and Edmunds, W. M. (2002) Use of abstraction regime and knowledge of hydrogeological conditions to control high-fluoride concentration in abstracted groundwater: San Luis Potosi basin, Mexico. J. Hydrol. 261, 24-47.

Chae, G., Yun, S., Kwon, M., Kim, Y. and Mayer, B. (2006) Batch dissolution of granite and biotite in water: Implication for fluorine geochemistry in groundwater. Geochem. $J$. 40, 95-102.

Chae, G., Yun, S., Mayer, B., Kim, K., Kim, S., Kwon, J., Kim, K. and Koh, Y. (2007) Fluorine geochemistry in bedrock groundwater of South Korea. Sci. Total Environ. 385, 272283.

Chang, B. L., Robbins, W. A., Wei, F., Xun, L., Wu, G., Li, N. and Elashoff, D. A. (2006) Boron workers in China: exploring work and lifestyle factors related to boron exposure. AAOHN J. 54, 435-443.

Council Directive 98/83/EC (1998) On the quality of water intended for human consumption. Official Journal of the European Communities L 330, 05/12/1998, 32-54.

Desbarats, A. (2009) On elevated fluoride and boron concentrations in groundwaters associated with the Lake SaintMartin impact structure, Manitoba. Appl. Geochem. 24, 915927.

Du, J., Wu, D., Xiao, H. and Li, P. (2011) Adsorption of fluoride on clay minerals and their mechanisms using X-ray photoelectron spectroscopy. Front. Environ. Sci. En. 5(2), 212-226.

Earle, S. and Krogh, E. (2006) Elevated fluoride and boron levels in groundwater from the Nanaimo group, Vancouver Island, Canada. Sea to Sky Geotechnique 2006: Proceedings of 59th Canadian Geotechnical Conference and 7th Joint CGS/IAH Groundwater Specialty Conference, 1584-1591.

Garabrant, D. H., Bernstein, L., Peters, J. M. and Smith, T. J. (1985) Respiratory effects of borax dust. Br. J. Ind. Med. 42, 831-837.

Gemici, Ü. and Tarcan, G. (2002) Distribution of boron in thermal waters of western Anatolia, Turkey, and examples of their environmental impacts. Environ. Geol. 43, 87-98.

Gonfiantini, R. and Pennisi, M. (2006) The behaviour of boron isotopes in natural waters and in water-rock interactions. $J$. Geochem. Explor. 88, 114-117.

Hem, J. D. (1985) Study and interpretation of the chemical characteristics of natural water. USGS Water Supply Paper 2254.

Hints, R., Kirsimäe, K., Somelar, P., Kallaste, T. and Kiipli, T. (2008) Multiphase Silurian bentonites in the Baltic Palaeobasin. Sediment. Geol. 209, 69-79.

Indermitte, E. (2010) Exposure to fluorides in drinking water and dental fluorosis risk among the population of Estonia. Dissertationes Geographicae Universitatis Tartuensis 41, Tartu University Press.

Indermitte, E., Saava, A. and Karro, E. (2009) Exposure to high fluoride drinking water and risk of dental fluorosis in Estonia. Int. J. Env. Res. Pub. He. 6(2), 710-721.

Karro, E. and Rosentau, A. (2005) Fluoride levels in the Silurian-Ordovician aquifer system of western Estonia. Fluoride 38(4), 307-311.
Karro, E. and Uppin, M. (2013) The occurrence and hydrochemistry of fluoride and boron in carbonate aquifer system, central and western Estonia. Environ. Monit. Assess. 185(5), 3735-3748.

Karro, E., Indermitte, E., Saava, A., Haamer, K. and Marandi, A. (2006) Fluoride occurrence in publicly supplied drinking water in Estonia. Environ. Geol. 50, 389-396.

Karro, E., Marandi, A., Vaikmäe, R. and Uppin, M. (2009) Chemical peculiarities of the Silurian-Ordovician and Cambrian-Vendian aquifer systems in Estonia: an overview of hydrochemical studies. Est. J. Earth Sci. 58, 342-352.

Kiipli, T., Soesoo, A., Kallaste, T. and Kiipli, E. (2008) Geochemistry of Telichian (Silurian) K-bentonites in Estonia and Latvia. J. Volcanol. Geoth. Res. 171, 45-58.

Kundu, N., Panigrahi, M. K., Tripathy, S., Munshi, S., Powell, M. A. and Hart, B. R. (2001) Geochemical appraisal of fluoride contamination of groundwater in the Nayagarh District of Orissa, India. Environ. Geol. 41, 451-460.

Mamatha, P. and Rao, S. M. (2010) Geochemistry of fluoride rich groundwater in Kolar and Tumkur districts of Karnataka. Environ. Earth Sci. 61, 131-142.

Mather, J. D. and Porteous, N. C. (2001) The Geochemistry and its isotopes in groundwaters from marine and nonmarine sandstone aquifers. Appl. Geochem. 16, 821-834.

Naseem, S., Rafique, T., Bashir, E., Bhanger, M. I., Laghari, A. and Usmani, T. H. (2010) Lithological influences on occurrence of high-fluoride groundwater in Nagar Parkar area, Thar Desert, Pakistan. Chemosphere 78, 1313-1321.

Nestor, H. and Einasto, R. (1997) Ordovician and Silurian carbonate sedimentation basin. Geology and Mineral Resources of Estonia (Raukas, A. and Teedumäe, A., eds.), 192-204, Estonian Academy Publishers.

Özgur, N. (2001) Origin of high boron contents of the thermal waters of Kizildere and Vicinity, western Anatolia, Turkey. Int. Geol. Rev. 43(10), 910-920.

Parkhurst, D. L. and Appelo, C. A. J. (1999) User's guide to PHREEQC (version 2) - a computer program for speciation, batch-reaction, one.dimensional transport, and inverse geochemical calculations. USGS Water-Resources Investigations Report 99-4259.

Pennisi, M., Bianchini, G., Muti, A., Kloppmann, W. and Gonfiantini, R. (2006) Behaviour of boron and strontium isotopes in groundwater-aquifer interactions in Cornia Plain (Tuscany, Italy). Appl. Geochem. 21, 1169-1183.

Perens, R. and Vallner, L. (1997) Water-bearing formation. Geology and Mineral Resources of Estonia (Raukas, A. and Teedumäe, A., eds.), 137-145, Estonian Academy Publishers.

Perens, R., Savva, V., Lelgus, M. and Parm, T. (2001) The Hydrogeochemical Atlas of Estonia (CD version). Geological Survey of Estonia.

Price, C. J., Marr, M. C., Myeos, C. B., Seely, J. C., Heindel, J. J. and Schwetz, B. A. (1996) The developmental toxicity of boric acid in rabbits. Fundam. Appl. Toxicol. 34, 176-187.

Queste, A., Lacombe, M., Hellmeier, W., Hillermann, F., Bortulussi, B., Kaup. M., Ott, K. and Mathys, W. (2001) High concentrations of fluoride and boron in drinking water wells in the Muenster region-Results of a preliminary investigation. Int. J. Hyg. Envir. Heal. 203, 221-224. 
Rafique, T., Naseem, S., Bhanger, M. I. and Usmani, T. H. (2008) Fluoride ion contamination in the groundwater of Mithi sub-district, the Thar Desert, Pakistan. Environ. Geol. 56, 317-326.

Raukas, A. and Teedumäe, A. (1997) Geology and Mineral Resources of Estonia. Estonian Academy Publishers.

Reddy, D. V., Nagabhushanam, P., Sukhija, B. S., Reddy, A. G. S. and Smedley, P. L. (2010) Fluoride dynamics in the granitic aquifer of the Wailapally watershed, Nalonga District, India. Chem. Geol. 269, 278-289.

Saxena, V. K. and Ahmed, S. (2001) Dissolution of fluoride in groundwater: a water-rock interaction study. Environ. Geol. 40, 1084-1087.

Saxena, V. K. and Ahmed, S. (2003) Inferring the chemical parameters for the dissolution of fluoride in groundwater. Environ. Geol. 43, 731-736.

Somelar, P., Kirsimäe, K., Hints, R. and Kirs, J. (2010) Illitization of Early Paleozoic K-Bentonites in the Baltic Basin: decoupling of burial- and fluid-driven processes. Clay. Clay Miner. 58, 388-398.

Sreedevi, P. D., Ahmed, S., Made, B., Ledoux, E. and Gandol, J. M. (2006) Association of hydrogeological factors in temporal variations of fluoride concentration in a crystalline aquifer in India. Environ. Geol. 50, 1-11.

Sujatha, D. (2003) Fluoride levels in the groundwater of the south-eastern part of Ranga Reddy district, Andhra Pradesh, India. Environ. Geol. 44, 587-591.

Taylor, J. C. (1991) Computer programs for standardless quantitative analysis of minerals using the full powder diffraction profile. Powder Diffr. 6(1), 2-9.

Uppin, M. and Karro, E. (2012) Geological sources of boron and fluoride anomalies in Silurian-Ordovician aquifer system, Estonia. Environ. Earth Sci. 65(4), 1147-1156.

Ward, C. R., Taylor, J. C., Matulis, C. E. and Dale, L. S. (2001) Quantification of mineral matter in the Argonne Premium Coals using interactive Rietveld-based X-ray diffraction. Int. J. Coal Geol. 46(2-4), 67-82.

Watson, M. E. (1998) Boron. Recommended Chemical Soil Test Procedures for the North Central Region (Brown, J. R., ed.), 45-48, Missouri Agricultural Experiment Station SB1001, North Central Regional Research Publication No. 221.

Wegman, D. H., Eisen, E. A., Hu, X., Woskie, S. R., Smith, R. S. and Garabrandt, D. (1994) Acute and chronic respiratory effects of sodium borate particulate exposures. Environ. Health. Perspect. 102, 119-128.

WHO (2008) Guidelines for Drinking-Water Quality. 3rd ed., World Health Organization, Geneva, Switzerland.

$\mathrm{Xu}$, L., Luo, K., Feng, F. and Tan, J. (2006) Studies on the chemical mobility of fluorine in rocks. Fluoride 39(2), 145151 . 